\title{
Wybrane regulacje Kodeksu spółek handlowych w świetle konstytucyjnego modelu ochrony własności
}

\section{Wprowadzenie}

W niniejszym artykule zostanie dokonana konfrontacja określonych rozwiązań przyjętych w Kodeksie spółek handlowych ${ }^{1}$ z wzorcami kontroli konstytucyjności prawa wynikającymi z Konstytucji Rzeczypospolitej Polskiej ${ }^{2}$. Przeprowadzone rozważania służą ukazaniu ewentualnej specyfiki rozwiązań prawa handlowego ${ }^{3}$, a także wyznaczeniu za pomocą uzyskanych spostrzeżeń kryteriów dokonywania zmian w k.s.h., które odpowiadałyby standardowi ochrony własności i innych praw podmiotowych wymaganemu przez Konstytucję RP. Celem opracowania jest wyjaśnienie miejsca prawa handlowego w systemie konstytucyjnym oraz udzielenie odpowiedzi na pytanie, jak instytucje prawa gospodarczego powinny być formowane, aby pozostawały w zgodzie ze standardami wytyczanymi przez ustawę zasadniczą. Punktem wyjścia dla podjętego dalej wywodu jest postawienie hipotezy, że tak jak w prawie

${ }^{1}$ Ustawa z dnia 15 IX 2000 r. Kodeks spółek handlowych (Dz.U. Nr 94, poz. 1037), dalej "k.s.h.”.

${ }^{2}$ Konstytucja Rzeczypospolitej Polskiej z dnia 2 IV 1997 r. (Dz.U. Nr 78, poz. 483 ze zm.), dalej „Konstytucja RP” lub „Konstytucja”.

${ }^{3}$ Dodać należy, że prawo handlowe samo w sobie - pomijając kwestię, czy stanowi ono odrębną gałąź, czy zaledwie dział prawa - cechuje się znaczną specyfiką. Zob. np. J. Okolski, D. Opalska, Pojęcie i specyfika prawa handlowego, w: Prawo handlowe, pod red. J. Okolskiego, M. Modrzejewskiej, Warszawa 2012, s. 31-40. 
prywatnym - pomimo raczej niekwestionowanej ${ }^{4}$ zasady jedności $^{5}$ prawa cywilnego ${ }^{6}$ - prawo handlowe, a zwłaszcza prawo spółek (czego skutkiem jest odpowiednie stosowanie przepisów Kodeksu cywilne$\left.\mathrm{go}^{7}\right)^{8}$ - posiada autonomię ${ }^{9}$ (zasada autonomii prawa handlowego ${ }^{10}$ ), tak i na płaszczyźnie konstytucyjnej przyjmowanie autonomiczności prawa handlowego jest zarówno legitymizowane, jak i pożądane. Autonomiczność prawa handlowego w prawie konstytucyjnym oznaczałaby, że Konstytucja, dostrzegając swoistość prawa handlowego, zawierałaby odmiennie wyznaczany standard ochrony określonych wartości w przypadku regulacji dotyczących tylko tej dziedziny. Determinowałoby to sposób oceny zgodności poszczególnych regulacji z ustawą zasadnicza, wpływając zarazem na ich interpretację. Podobne podejście in concreto w sprawie konstytucyjności squeeze-out (co będzie przedmiotem omówienia w dalszej części rozważań) zaprezentował Trybunał Konstytucyjny (TK), stwierdzając, że "punktem wyjścia oceny konstytucyjności zakwestionowanych przepisów kodeksu spółek handlowych powinna być charakterystyka istoty spółek kapitałowych, praw inkorporowanych przez akcje"11, a także istoty konkretnej konstrukcji stanowiącej przed-

${ }^{4}$ Przy czym w doktrynie można spotkać opinie wskazujące na dekompozycję prawa cywilnego i podnoszące tym samym wątpliwości wobec samej zasady jedności prawa cywilnego. Tak P. Stec, Kodeks cywilny - między dekodyfikacja a rekodyfikacja, w: 50 lat kodeksu cywilnego. Perspektywa rekodyfikacji, pod red. P. Steca, M. Załuckiego, Warszawa 2015, s. 25-44.

${ }^{5}$ Por. S. Włodyka, Prawo handlowe a zasada jedności prawa cywilnego, w: System Prawa Handlowego, t. 1: Prawo handlowe - część ogólna, pod red. S. Włodyki, Warszawa 2009, s. 8-14, 46 i n.; A. Wolter, J. Ignatowicz, K. Stefaniuk, Prawo cywilne. Zarys części ogólnej, Warszawa 2001, s. 22-24.

${ }^{6}$ A. Stelmachowski, Zasada jedności prawa cywilnego (Teoria i praktyka), „Przegląd Ustawodawstwa Gospodarczego" 1980, nr 2, s. 37-43; idem, Zasada jedności prawa cywilnego - teoria i praktyka, "Acta UNC Prawo" 1982, nr 20, s. 5-18.

${ }^{7}$ Ustawa z dnia 23 IV 1964 r. - Kodeks cywilny (tekst jedn. Dz.U. 2018, poz. 1025).

${ }^{8}$ M. Pazdan, Kodeks spótek handlowych a kodeks cywilny, "Państwo i Prawo" 2001, nr 2; S. Sołtysiński, Przepisy ogólne kodeksu spółek handlowych (Wybrane zagadnienia), „Państwo i Prawo" 2001, nr 7, s. 3-25; A. Szumański, Nowe polskie prawo spółek handlowych, "Przegląd Prawa Handlowego" 2001, nr 1, s. 7-11; T. Siemiątkowski, R. Potrzeszcz, Komentarz do kodeksu spótek handlowych. Spótki osobowe, Warszawa 2001, s. 31-32.

${ }^{9}$ Por. M. Rodzynkiewicz, Kodeks spótek handlowych. Komentarz, Warszawa 2014, s. 13; J. Napierała, T. Sójka, Kodeks spółek handlowych, w: Prawo spółek handlowych. Podręcznik akademicki, pod red. A. Kocha, J. Napierały, Warszawa 2011, s. 31 i n.

${ }^{10}$ S. Sołtysiński, Spóźniona reforma prawa spótek handlowych, „Przegląd Prawa Handlowego" 1999, nr 5, s. 1-12; P. Antoszek, Cywilnoprawny charakter uchwał wspólników spółek kapitałowych, Warszawa 2009, s. 139-141, i przywoływana tam literatura.

${ }^{11}$ Wyrok TK z 21 VI 2005 r., sygn. P 25/02, OTK-A 2005, nr 6, poz. 65. 
miot danej sprawy. Z leżącego u podstaw tej myśli rozumowania można wyinterpretowywać argumenty dla poszukiwania autonomicznego podejścia konstytucyjnego do prawa spółek handlowych.

\section{Możliwość swoistej oceny prawa handlowego na gruncie Konstytucji RP}

Jak już powyżej zasygnalizowano, problematyka artykułu koncentruje się na instytucjach zawartych w k.s.h. w kontekście ich zgodności głównie z konstytucyjnym wzorcem ochrony własności ${ }^{12}$. Na wstępie podkreślić należy, że uzasadnienia dla suwerennej oceny prawa handlowego poszukiwać można jedynie w samej ustawie zasadniczej, która stosownie do art. 8 i 87 stawia siebie na czele hierarchii źródeł prawa powszechnie obowiązującego, a jej przepisy obowiązują bezpośrednio ${ }^{13}$. Spostrzeżenie to - samo w sobie będące truizmem - nakazuje jednak zaledwie badanie, w jaki sposób i w jakim stopniu model ochrony własności i innych praw podmiotowych przyjęty w polskiej Konstytucji ${ }^{14}$ determinuje kształt obowiązujących przepisów k.s.h. Natomiast nie stoi ono na przeszkodzie dopatrywania się w ramach owego modelu zróżnicowania standardów. Takie różnicowanie kryteriów oceny siłą rzeczy wiąże się z konstytucyjną zasadą równości, prowadząc do konieczności odpowiedzi na pytanie o dopuszczalność dyferencjacji interpretacji wzorców kontroli konstytucyjności w zależności od przedmiotu kontroli i podmiotów, których on dotyczy.

W orzecznictwie TK już na początku jego działalności ${ }^{15}$ sformułowane zostało zasługujące na aprobatę stanowisko odnośnie do sposobu rozumienia równości. Jak bowiem stwierdził Trybunał, „konstytucyjna zasada równości polega na tym, że wszystkie podmioty prawa (adresaci norm prawnych), charakteryzujące się daną cechą istotną (relewantną) w równym stopniu, mają być traktowane równo. A więc według jednakowej miary, bez zróżnicowań zarówno dyskryminujących, jak

${ }^{12}$ S. Jarosz-Żukowska, Prawo do własności - własność jako prawo podmiotowe, w: Prawa $i$ wolności obywatelskie w Konstytucji RP, pod red. B. Banaszaka, A. Preisnera, Warszawa 2002.

${ }^{13}$ L. Garlicki, Polskie prawo konstytucyjne. Zarys wykładu, Warszawa 2006, s. 128 i n.

${ }^{14}$ M. Jagielski, Regulacja własności w Konstytucji RP. Podstawowe dylematy, w: Państwo i prawo wobec współczesnych wyzwań. Zagadnienia prawa konstytucyjnego. Księga Jubileuszowa Profesora Jerzego Jaskierni, pod red. M. Czarnego, K. Spryszaka, Toruń 2012.

15 Orzeczenie TK z 9 III 1988 r., sygn. U 7/87, OTK 1986-1995/t1/1988/1. 
i faworyzujących". Dla zastosowania zasady równości warunkiem sine qua non jest zatem uprzednie ustalenie określonej cechy relewantnej, która stanowić będzie kryterium nakazujące traktować podmioty tę cechę posiadające w sposób identyczny. A contrario zatem $\mathrm{z}$ tego rozumowania wynika, że podmioty o różnych cechach nie muszą być traktowane tak samo, ergo na gruncie zasady równości możliwe jest odmienne traktowanie. Dalej bowiem w uzasadnieniu wyżej cytowanego orzeczenia można przeczytać, że równość „oznacza także akceptację różnego traktowania przez prawo różnych podmiotów (adresatów norm prawnych), bo równe traktowanie przez prawo tych samych podmiotów pod pewnym względem oznacza $\mathrm{z}$ reguły różne traktowanie tych samych podmiotów pod innym względem"16. Pomimo sformułowania powyższych tez na gruncie Konstytucji PRL ${ }^{17}$, zachowują one aktualność i obecnie, wyznaczając kryteria dyferencjacji sytuacji prawnej podmiotów i oddziałując zarazem na zakres innych wolności i praw. To odmienne traktowanie może być uzasadnione przynależnością do materii objętej specyficzną metodą i przedmiotem regulacji. Przykład może tu stanowić właśnie m.in. przynależność do reżimu prawa handlowego. Tak ujętą zasadę równości należy rozpatrywać nie tylko w kontekście jej samej, ale także w kontekście określania standardów wynikających z innych praw i wolności konstytucyjnych wobec różnych podmiotów - w tym i zasady ochrony własności ${ }^{18}$. Dlatego też dla możliwości odrębnego, autonomicznego względem reguł ogólnych stosowania konstytucyjnego prawa własności ${ }^{19}$ wobec instytucji k.s.h. wykazać należy, że podleganie regulacji prawa spółek handlowych oznacza posiadanie pewnej cechy relewantnej, która legitymizowałaby odmienne reguły interpretacyjne i standardy ochrony wynikające z konstytucyjnej zasady ochrony własności i innych praw podmiotowych. Proponowane tutaj podejście metodologiczne powinno korespondować $\mathrm{z}$ dotychczas wypracowanymi przez TK uwagami poczynionymi przy kontroli konstytucyjności instytucji k.s.h. Pewną wskazówkę dla ustalenia relewantności przy ocenie zasady równości dostarcza art. 20 k.s.h. Konstytucyjna

${ }^{16}$ Orzeczenie TK z 9 III 1988 r., sygn. U 7/87.

${ }^{17}$ Konstytucja Polskiej Rzeczypospolitej Ludowej z dnia 22 VII 1952 r., Dz.U. 1952 Nr 33, poz. 232 ze zm.

${ }_{18}$ C. Kosikowski, Zasada ochrony własności, w: Zasady podstawowe polskiej konstytucji, pod red. W. Sokolewicza, Warszawa 1998.

${ }_{19}$ T. Dybowski, Własność w przepisach konstytucyjnych wedle stanu obowiazujacego w 1996 r., w: Konstytucja i gwarancje jej przestrzegania. Ksiegga pamiątkowa ku czci prof. Janiny Zakrzewskiej, pod red. J. Trzcińskiego, A. Jankiewicz, Warszawa 1996, s. 315. 
zasada równości na obszarze prawa spółek przyjęła bowiem normatywny kształt $\mathrm{w}$ postaci zasady równego traktowania akcjonariuszy, która bynajmniej nie oznacza równości praw w spółce akcyjnej ${ }^{20}$. Zasada równego traktowania akcjonariuszy stanowiąca operacjonalizację konstytucyjnej zasady równości oznacza proporcjonalność praw do wkładów ${ }^{21}$.

\section{Przymusowy wykup akcjonariuszy wobec standardów wyznaczonych przez Konstytucję RP}

Jedną z budzących bodajże największe emocje i zastrzeżenia w przedmiocie zgodności z konstytucyjną ochroną własności regulacji była konstrukcja przymusowego wykupu akcjonariuszy. Zarazem stanowi ona doskonały przykład dowodzący tezy o autonomiczności instytucji prawa handlowego, która to autonomiczność znajduje miejsce w ramach konstytucyjnego modelu ochrony praw majątkowych. W związku z tym została ona wybrana jako reprezentatywna dla założeń niniejszego artykułu.

Instytucja przymusowego wykupu akcjonariuszy, zwana także od jej angielskiej nazwy "wyciskaniem akcjonariuszy", nie miała swojego odpowiednika na gruncie uprzednio obowiązującego kodeksu handlowe$\mathrm{go}^{22}$. Stanowi ona zatem novum wprowadzone przez k.s.h. w ślad za ustawodawstwem państw unijnych ${ }^{23}$. Przymusowy wykup oznacza, że walne zgromadzenie akcjonariuszy (WZA) kontrolowane przez maksymalnie pięciu akcjonariuszy większościowych, z których każdy reprezentuje minimum 5\% kapitału zakładowego, może podjąć uchwałę o wykupie akcjonariuszy mniejszościowych (reprezentujących nie więcej niż 5\% kapitału zakładowego). Tuż po jej wejściu w życie zwracano uwagę, że „do natury spółki akcyjnej należą rządy większości nad mniejszością oraz prymat kapitału nad osoba, toteż przymusowego wykupu akcji drobnego akcjonariusza nie można traktować w kategoriach naruszania

\footnotetext{
${ }^{20}$ Tak też TK w wyroku z 21 VI 2005 r., sygn. P 25/02, OTK ZU 2005/6A/65.

${ }^{21}$ S. Sołtysiński, L. Moskwa, Próby doktrynalnego wyjaśnienia natury spółek kapitałowych, w: System Prawa Prywatnego, t. 17A: Prawo spółek kapitałowych, pod red. S. Sołtysińskiego, Warszawa 2015, s. 21-22.

${ }^{22}$ Rozporządzenie Prezydenta Rzeczypospolitej z dnia 27 X 1933 r. - Kodeks handlowy (Dz.U. Nr 82, poz. 600).

${ }^{23}$ A. Całus, Przymusowy wykup drobnych akcjonariuszy - uwagi prawnoporównawcze, w: Studia z prawa prywatnego gospodarczego. Ksiega pamiatkowa ku czci prof. Ireneusza Weissa, Kraków 2003, s. 25.
} 
konstytucyjnego prawa własności"24. Jednak spotkać można było także opinie, które, wskazując wyjątkowość tej instytucji, postulują na podstawie tego „konieczność narzucenia rygorystycznych ograniczeń jej stosowania" 25 , a także dostrzegają podobieństwa przymusowego wykupu akcji do „niepełnego zniesienia współwłasności” ${ }^{26}$. W doktrynie zauważono również, że „instytucja przymusowego wykupu stanowi swoisty wyjątek od zasady swobody rozporządzania akcjami (art. 337 $\S 1 \mathrm{KSH}$ ), z której wynika zakaz przymuszania akcjonariusza do obowiązku objęcia, nabycia akcji"27.

Instytucja squeeze-out ma dwie podstawy normatywne: obok przytaczanego już art. 418 k.s.h. jest nim art. 82 ustawy o ofercie publicznej ${ }^{28}$ w odniesieniu do spółek publicznych. Należy się zgodzić z poglądem, że przepisy te są wobec siebie niezależne ${ }^{29}$, tworząc razem system przymusowego wykupu. Już w momencie jej wprowadzenia w doktrynie ${ }^{30}$ podnoszono, że stanowi ona wyraz zastosowania ekonomicznego podejścia w prawie spółek ${ }^{31}$. Zarazem centralnym zagadnieniem, obok dopuszczalności wykupu, ściśle z nią powiązanym i warunkującym ja, była ochrona praw majątkowych akcjonariusza mniejszościowego ${ }^{32}$. Pomimo że cel instytucji służyć ma w zamierzeniu akcjonariuszom większościowym, interes drobnych akcjonariuszy musi więc zostać w prawnej regulacji uwzględniony. Jak pisał Andrzej Szumański ${ }^{33}$, "chodzi tu o to, aby drobni akcjonariusze: po pierwsze, otrzymali rynkową

\footnotetext{
${ }^{24}$ A. Szumański, Prymat kapitału nad osoba, „Rzeczpospolita” 14 II 2001, nr 38(5811), dział "Prawo co dnia".

${ }^{25}$ Tak P. Wierzbicki, Uchwała o przymusowym wykupie akcji, „Prawo Spółek” 2004, nr 11, s. 24.

${ }^{26}$ M. Zaremba, Instytucja przymusowego wykupu akcji na tle orzeczenia TK z 21 czerwca 2005 r., "Radca Prawny” 2006, nr 2, s. 67.

27 A. Slisz, Prymat większości, ochrona mniejszości. Przymusowy wykup akcji w świetle proponowanych zmian, "Palestra” 2003, nr 7-8, s. 88.

${ }^{28}$ Ustawa z dnia 29 VII 2005 r. o ofercie publicznej i warunkach wprowadzania instrumentów finansowych do zorganizowanego systemu obrotu oraz o spółkach publicznych (Dz.U. Nr 184, poz. 1539).

${ }_{29}$ Tak A. Puchalski, Polska regulacja przymusowego wykupu akcji w spótkach publicznych na tle prawa unijnego, "Przegląd Prawa Handlowego" 2015, nr 1, s. 45.

${ }^{30}$ R.T. Stroiński, Cele oraz ryzyka przymusowego wykupu akcji w kodeksie spótek handlowych, "Przegląd Prawa Handlowego" 2001, nr 12, s. 19-28.

${ }^{31}$ Zob. także J. Warchol, Regulacja instytucji squeeze out $i$ reverse squeeze out w Unii Europejskiej, "Przegląd Prawa Handlowego" 2002, nr 12, s. 32-38.

32 A. Szumański, Przymusowy wykup akcji drobnych akcjonariuszy, "Przegląd Prawa Handlowego" 2001, nr 11, s. 1.

${ }^{33}$ Warto podkreślić, że autor ten jest jednym z twórców Kodeksu spółek handlowych.
} 
wartość swoich akcji i po drugie, aby cena wykupu została niezwłocznie uiszczona"34. Później, w 2005 r., w wyniku nowelizacji k.s.h. dodano niejako lustrzane uprawnienie dla akcjonariuszy mniejszościowych w postaci sell out ${ }^{35}$, które bez wattpienia ma wzmocnić wykonywanie ich praw majątkowych ${ }^{36}$.

Instytucja ta od samego początku budziła jednak zastrzeżenia. Poza wątpliwościami natury prawnokonstytucyjnej - o których mowa będzie dalej $^{37}$ - krytykę wzbudziła znaczna liczba odesłań w sposób kaskadowy oraz niepełność regulacji w postaci pominięcia wykupu akcji obciążonych prawami osób trzecich ${ }^{38}$. W dodatku możliwość wykupu akcji wbrew woli podmiotu uprawnionego prowadziła do podniesienia zarzutów naruszenia konstytucyjnego prawa własności ${ }^{39}$. Ponadto zwracano uwagę na iluzoryczność ochrony akcjonariusza, wykluczanego z powodu sposobu skonstruowania art. 418 k.s.h., który statuując ustawowe prawo wykluczenia, nie wymagał zarazem uzasadnienia podejmowanej uchwały, co miało czynić nieprawdopodobnym uwzględnienie przez sąd powództwa o uchylenie uchwały ${ }^{40}$.

Zawężeniem instytucji wyciskania akcjonariuszy jest ograniczenie jej zastosowania tylko do w pełni "czystego" kapitałowego charakteru spółki: jeżeli akcjonariuszom przysługują uprawnienia o charakterze osobistym, przeprowadzenie squeeze-out jest niedopuszczalne ${ }^{41}$. Zważywszy zatem na surowe wymogi dla aktualizacji możliwości

\footnotetext{
${ }^{34}$ A. Szumański, Przymusowy wykup akcji..., s. 1.

${ }^{35}$ Por. D. Nowak, Squeeze out a sell out - porównanie, „Edukacja Prawnicza” 2006, nr 6(81), s. 25.

${ }^{36}$ Zob. także M. Pawełczyk, P. Sokal, Podatkowe aspekty przymusowego wykupu i odkupu akcji, „Prawo Spółek” 2011, nr 11, s. 31.

${ }^{37}$ Pozostałe zarzuty wobec tej instytucji nie będą jednak analizowane w niniejszym artykule, gdyż jego celem nie jest wyczerpujące omówienie regulacji wyciśnięcia akcjonariuszy, tylko ukazanie za jej pomocą złożoności materii prawa spółek handlowych wobec k.s.h. i wynikającej z niej potrzeby oraz zasadności autonomicznej wykładni i oceny konstytucyjności.

${ }^{38}$ Por. M. Stanik, Uwagi do art. 418 KSH. Przesłanki podmiotowe i przedmiotowe przymusowego wykupu akcji, „Przegląd Ustawodawstwa Gospodarczego” 2007, nr 8, s. 23.

${ }^{99}$ P. Bielski, Przymusowy wykup akcji drobnych akcjonariuszy a natura spółki akcyjnej, „Przegląd Prawa Handlowego" 2001, nr 11, s. 11-19.

${ }^{40}$ Tak. E. Marszałkowska-Krześ, Komentarz do art. 418, w: Spółka akcyjna. Komentarz, pod red. J. Okolskiego, Warszawa 2001, s. 265. Autorka ta pisała nawet wtedy, że „art. 418 stanowi lex specialis w stosunku do art. 422", podnosząc zastrzeżenia co do jego konstytucyjności. Zob. ibidem.

${ }^{41}$ W. Popiołek, Spótka akcyjna, w: System Prawa Handlowego, t. 2: Prawo spółek handlowych, pod red. S. Włodyki, Warszawa 2012, s. 1074.
} 
wykupu - skupienia 95\% kapitału zakładowego w rękach nie więcej niż pięciu akcjonariuszy, z których każdy musi posiadać co najmniej $5 \%$, oraz konieczność braku jakichkolwiek uprawnień o charakterze osobistym, można postawić tezę, że instytucja ta dotyczy spółki akcyjnej o kwalifikowanym charakterze, gdzie kapitałowa natura uwidacznia się w sposób nadzwyczaj wyraźny. W spółce akcyjnej, która nie spełnia powyżej zakreślonych przesłanek, pomimo że jest ona przecież modelową spółką kapitałową ${ }^{42}$, nie ma możliwości wyzucia akcjonariuszy $z$ ich akcji wbrew ich woli. Przed dokonaną w 2003 r. reformą ${ }^{43}$ dopuszczalność squeeze-out opierała się na dwóch progach: uprawniającym i blokującym ${ }^{44}$, z tym że ten pierwszy wynosił $90 \%$. W porównaniu zatem z pierwotną regulacją wymóg w odniesieniu do akcjonariuszy większościowych został zaostrzony, wobec którego to rozwiązania wyrażono w doktrynie zarówno aprobatę ${ }^{45}$, jak i krytykę ${ }^{46}$.

\section{Stanowisko Trybunału Konstytucyjnego wobec problemu}

Istniejące od wejścia w życie k.s.h. wątpliwości co do konstytucyjności przymusowego wykupu musiały znaleźć swój finał w rozstrzygnięciu TK. W orzeczeniu o sygn. P 25/02 Trybunał stwierdził zgodność art. 418 k.s.h. z ustawą zasadniczą pod warunkiem, że rozumiany jest on jako niewykluczający możliwości zaskarżenia uchwały na podstawie art. 422 k.s.h. ${ }^{47}$ TK zdecydował się zatem rozstrzygnąć spór, opierając się na wyroku interpretacyjnym, gdzie wskazane zostaje rozumienie pozostające w zgodzie z Konstytucją RP. Istotę takich orzeczeń dobrze oddaje samo stwierdzenie Trybunału z uzasadnienia sprawy o sygn.

42 Abstrahując od problemu, czy modelową spółką kapitałową jest publiczna spółka akcyjna czy też prywatna.

${ }^{43}$ A. Radwan, Squeeze-out? Tak!, ale nie tak - kilka uwag na temat planowanej nowelizacji art. 418 KSH, „Prawo Spółek” 2003, nr 4, s. 48 i n.

${ }^{44}$ Por. A. Radwan, Aktualna i przyszła regulacja przymusowego wykupu akcji drobnych akcjonariuszy w polskim i europejskim prawie spółek, "Przegląd Legislacyjny” 2003, nr 6(40), s. 29-56, zwł. 37-41.

${ }^{45}$ Tak K. Oplustil, Wykluczenie akcjonariuszy mniejszościowych ze spółki (tzw. squeeze-out) w prawie europejskim, niemieckim i polskim. Analiza prawnoporównawcza z uwzględnieniem aspektu konstytucyjnego, "Studia Prawnicze” 2003, z. 1(155), s. 87.

${ }^{46}$ Tak A. Radwan. Zob. publikacje tego autora powołane w przyp. 43 i 44, a także idem, Regulacja przymusowego wykupu akcji drobnych akcjonariuszy - uwagi de lege ferenda, „Monitor Prawniczy" 2003, nr 11.

${ }^{47}$ Wyrok TK z 21 VI 2005 r., sygn. P 25/02. 
SK 22/9948: „Orzeczenie w sentencji wyroku, że dany przepis jest zgodny z konstytucją przy jego określonym rozumieniu, oznacza a contrario uznanie za niezgodne $\mathrm{z}$ konstytucją - i tym samym nieprawidłowe rozumienie przeciwne do wskazanego przez Trybunał. [...] Orzeczenie o zgodności przepisu z konstytucją oznacza przypisanie atrybutu konstytucyjności nie pewnej jednostce redakcyjnej bez względu na jej treść, lecz określonej treści normatywnej zawartej w tym przepisie, ustalonej w wyniku interpretacji". Pomimo kategoryczności tego stwierdzenia i powszechnej mocy obowiązującej orzeczeń Trybunału sądy nie zawsze stosują się do zawartej w nich interpretacji ${ }^{49}$. Zarazem w uzasadnieniu orzeczenia zawarta została swoista przesłanka uzupełniająca wydane rozstrzygnięcie w postaci konieczności uzasadnienia uchwały o wykupie dla urzeczywistnienia prawa do zaskarżenia w sensie materialnym. Trybunał w uzasadnieniu skonstruował w sposób prawotwórczy wymóg, którego podstaw na próżno szukać w k.s.h., co spotkało się ze słuszną krytyką ${ }^{50}$ podkreślającą sprzeczność z wyraźnymi intencjami ustawodawcy ${ }^{51}$. Wobec mających miejsce przypadków braku zastosowania się do samych sentencji orzeczeń interpretacyjnych nie dziwi fakt, że orzecznictwo nie stosuje się do kontrowersyjnego wymogu z uzasadnienia $^{52}$. W dodatku wobec takiego rozstrzygnięcia podniesiono, że „dopuszczenie pozanormatywnej przesłanki obowiązku uzasadnienia uchwały o przymusowym wykupie (czyli wymogu podawania motywów tego wykupu) oznacza w konsekwencji wypaczenie woli ustawodawcy

${ }^{48}$ Wyrok TK z 8 V 2000 r., sygn. SK 22/99, OTK ZU 2000, nr 4, poz. 107.

${ }^{49}$ Posługiwanie się formą wyroku interpretacyjnego miało stosunkowo często miejsce na przełomie tysiącleci. Wypracowanie tej postaci orzeczenia uznać można za reminiscencję działalności wykładniczej sprzed wejścia w życie Konstytucji z 1997 r., kiedy to TK posiadał uprawnienia do podejmowania uchwał wykładniczych, i wyraz swoistej nostalgii za utraconą kompetencją. Obok wyroków zakresowych wyroki interpretacyjne umożliwiały wpływ na praktykę stosowania prawa. Jednakże analiza najnowszych orzeczeń Trybunału pokazuje, że w ostatnim czasie TK coraz rzadziej sięga do konstrukcji orzeczenia interpretacyjnego. Zob. M. Wiącek, Odstapienie przez Trybunat Konstytucyjny od swojego wcześniejszego poglądu prawnego, „Przegląd Legislacyjny” 2007, nr 2, s. 58.

${ }^{50}$ Za wyjątkowe, czy wręcz "egzotyczne" uznać można opinie upatrujące w orzeczeniu TK "ucywilizowania" przymusowego wykupu. Tak W. Gontarski, Przymusowy wykup akcji troche mniej przymusowy, "Gazeta Sądowa” 2007, nr 6, s. 41-42.

${ }^{51}$ A. Szumański, Pokrzywdzenie akcjonariusza oraz sprzeczność z dobrymi obyczajami jako przesłanki uchylenia uchwały walnego zgromadzenia spółki akcyjnej o przymusowym wykupie akcji, „Przegląd Prawa Handlowego" 2006, nr 3, s. 6.

${ }_{52}$ Zwraca na to uwage Szymon Byczko. Zob. S. Byczko, Przymusowy wykup akcji akcjonariuszy mniejszościowych - uwagi w 10 lat po wyroku w sprawie P 25/02, "Przegląd Prawa Handlowego" 2015, nr 9, s. 34. 
z art. $418 \S 1$ k.s.h. i jednocześnie próbę niedozwolonego systemowego zbliżenia przymusowego wykupu akcji drobnych akcjonariuszy [...] do instytucji wyłączenia wspólnika ze spółki z o.o., uregulowanej w art. 266-269 $\mathrm{KSH}^{\prime 53}$. Głębsza analiza stanowiska z punktu widzenia systemowego wykraczałaby jednak poza ramy i cel niniejszego artykułu. Dlatego skupiając się jedynie na aspekcie prawnokonstytucyjnym, należy stwierdzić, że u podłoża wydanego orzeczenia tylko częściowo znajduje się specyfika instytucji prawa spółek na gruncie ochrony konstytucyjnych praw. Pomimo że w uzasadnieniu dostrzec można dla takiego rozumowania podstawy, Trybunał Konstytucyjny trafnie zaakcentował zasadę rządów większości nad mniejszością oraz zasadę proporcjonalności praw i wkładów ${ }^{54}$. Zarazem podzielając uzyskaną konkluzję, że „koncepcja przymusowego wykupu akcji drobnych akcjonariuszy jest zgodna z naturą spółki akcyjnej" ${ }^{\prime 55}$, można dostrzec brak pewnego ogniwa w łańcuchu elementów składających się na rozumowanie do tej konkluzji prowadzącego. Dlatego też warto podjać próbę rozwinięcia myśli na temat prawa własności zapoczątkowanej w orzeczeniu, ale nierozwiniętej przez TK w sposób konsekwentny.

\section{Ocena przymusowego wykupu akcji w modelu ochrony własności w Konstytucji RP}

Szeroki zakres ochrony własności w prawie polskim został podkreślony w konstrukcji art. 64 Konstytucji RP, gdzie obok samego prawa własności mowa jest o prawie dziedziczenia oraz innych prawach majątkowych ${ }^{56}$. Takie uregulowanie podkreślić ma znaczenie prawa własności w polskim systemie prawnym, być może także ze względu na zaszłości historyczne, w opozycji do braku poszanowania własności prywatnej w poprzednim systemie społeczno-gospodarczym PRL ${ }^{57}$. W każdym razie dla precyzji prowadzonego wywodu należy zaznaczyć, że w niniejszym artykule pojęcie własności używane będzie w szerokim znaczeniu, obejmującym inne prawa majątkowe, o których mowa w ust. 2 art. 64 ustawy

${ }^{53}$ A. Szumański, Pokrzywdzenie akcjonariusza..., s. 5.

${ }^{54}$ Zob. pkt 4.8 do 4.12 uzasadnienia do wyroku P 25/02.

${ }^{55}$ Zob. pkt 4.11 uzasadnienia orzeczenia TK o sygn. P 25/02.

${ }^{56}$ R. Balicki, M. Bartoszewicz, K. Complak, M. Haczkowska, A. Ławniczak, M. Masternak-Kubiak, Konstytucja Rzeczypospolitej Polskiej. Komentarz, Warszawa 2014, komentarz do art. 64 dostępny w Systemie Informacji Prawnej LEX.

${ }^{57}$ Por. W. Pańko, O prawie własności i jego współczesnych funkcjach, Katowice 1994. 
zasadniczej (własność sensu largo), np. akcje ${ }^{58}$. Nie ulega wątpliwości, że własność stanowi jedno z podstawowych praw człowieka ${ }^{59}$, na co zwraca się uwage $w$ doktrynie ${ }^{60} \mathrm{i}$ orzecznictwie ${ }^{61}$.

W doktrynie prawa konstytucyjnego ${ }^{62}$ podkreśla się, że ustrojodawca celowo posłużył się sformułowaniem o prawie "do własności", co gwarantuje nie tylko ochronę już posiadanej w sposób przez nikogo niekwestionowany własności, ale także ochronę prawa do otrzymania własności dobra lub do ustalenia tej własności w razie konfliktu ${ }^{63}$. Warto się zastanowić, jaki charakter ma to prawo. W doktrynie prawa konstytucyjnego wyróżnia się bowiem prawa pozytywne (uprawnienia), prawa wolnościowe oraz prawa-instytucje. W przypadku prawa do własności adekwatne jest posługiwanie się terminem "prawo-instytucja", wypracowanym w niemieckiej nauce o gwarancjach instytucjonalnych praw podstawowych ${ }^{64}$. Jest to osobna kategoria praw, które zapewniają ochronę przed ingerencją w sytuacje prawne jednostki, ukształtowane na gruncie norm prawa prywatnego ${ }^{65}$. Można by się zastanawiać, jakiego rodzaju i przed czym (albo przed kim) jest ta ochrona. W polskim systemie prawnym zdecydowano się dokonać podziału ochrony własności w ten sposób, że art. 21 Konstytucji RP - oprócz tego, że podkreśla znaczenie ochrony własności poprzez podniesienie jej do rangi zasady konstytucyjnej - jest, jak się zdaje, ukierunkowany (przynajmniej jego ust. 2) na ochronę przez naruszeniami ze strony władz publicznych,

${ }^{58}$ Takie autonomiczne zdefiniowanie własności rozumianej jako prawo majątkowe na potrzeby niniejszego artykułu uzasadnione jest tym, że w doktrynie prawa odróżnia się pojęcie własności i mienia także na gruncie konstytucyjnym. Zob. M. Chmaj, Wolności i prawa człowieka w Konstytucji Rzeczypospolitej Polskiej, Warszawa 2008, s. 156 i n.

${ }^{59}$ M. Balcerzak, Prawo do poszanowania mienia, w: Prawa człowieka $i$ ich ochrona, pod red. T. Jasudowicza, Torun 2005.

${ }^{60}$ S. Jarosz-Żukowska, Prawo do własności, w: Prawa i wolności I i II generacji, pod red. A. Florczaka, B. Bolechowa, Toruń 2006.

${ }^{61}$ Wyrok TK z 31 I 2001 r., sygn. P 4/99, OTK 2001, nr 1, poz. 5, w którym Trybunał na kanwie specjalnego reżimu dziedziczenia gospodarstw rolnych poczynił wiele cennych uwag na temat natury prawa własności i jego miejsca w demokratycznym państwie prawnym.

${ }^{62}$ Szczegółowe rozważania na ten temat zob. K. Nowakowska, P. Ochmann, Bankowy tytuł egzekucyjny jako instrument realizacji konstytucyjnie gwarantowanego prawa własności, „Przegląd Prawa Konstytucyjnego" 2016, nr 1, s. 101-125.

${ }^{63}$ B. Banaszak, Art. 64, w: Konstytucja RP. Komentarz, Warszawa 2012, dostępny także w Systemie Informacji Prawnej Legalis.

${ }^{64} \mathrm{~K}$. Wojtyczek, Granice ingerencji ustawodawczej w sfere praw człowieka w Konstytucji RP, Kraków 1999, s. 23.

${ }^{65}$ S. Jarosz-Żukowska, Konstytucyjna zasada ochrony własności, Kraków 2003, s. 83. 
a więc państwa realizującego imperium, podczas gdy art. 64 Konstytucji RP ma szerszy zakres. Można by racjonalnie argumentować, że chroni on także przed wywłaszczeniem prywatnym, którego emanację stanowiłaby np. instytucja przymusowego wykupu ${ }^{66}$. Prima facie zatem w sposób nieodparty nasuwa się konkluzja, że prawo własności akcjonariusza wykupywanego zostaje naruszone. Jednakże w ten sposób dokonywana jest ochrona prawa własności akcjonariusza większościowego, np. przed szantażem korporacyjnym. Ochrona przed wspólnikami mniejszościowymi stanowiła jedno z ratio legis wprowadzenia przymusowego wykupu do k.s.h. ${ }^{67}$ Wydaje się bezsporne, że wykonywanie prawa własności w postaci szantażu korporacyjnego nie powinno korzystać z ochrony - ani ustawowej, ani konstytucyjnej. Można w nim bowiem upatrywać nadużycia prawa podmiotowego ${ }^{68}$. Zastosowanie instytucji squeeze-out nie było i nie jest jednak w żaden sposób ograniczone do przypadków jakiegoś negatywnego zachowania po stronie akcjonariuszy mniejszościowych. Ma ono charakter zobiektywizowany ${ }^{69}$ : dla jego wykonania konieczne jest wyłącznie wystąpienie przesłanek z art. 418 k.s.h., które mają charakter matematyczny oraz proceduralny. Niemniej jednak, nawet gdy akcjonariusze mniejszościowi nie są odpowiedzialni za żadną przysłowiową "krecią robotę" względem akcjonariuszy większościowych, możliwość ich przymusowego wykupu pozwala w sposób łatwy osiągnąć zamknięty charakter spółki, która w sensie ekonomicznym w sposób przeważający „należy” do akcjonariuszy większościowych ${ }^{70}$. Niewątpliwie zatem ułatwia i wzmacnia realizację przysługującego im prawa własności. Takie wzmocnienie wpisuje się w ochronę tego prawa w świetle Konstytucji RP. Zarazem jednak nie odbywa się to w sposób neutralny wobec tego samego pod względem rodzajowym, ale słabszego pod względem ilościowym, prawa własności akcjonariuszy mniejszościowych. Warto zacytować w tym miejscu Ewę Lętowska, która pisze, że szerokość i zakres konstytucyjnych gwarancji przyznawanych w polskiej Konstytucji własności i innym prawom

${ }^{66} \mathrm{~W}$ doktrynie można spotkać postrzeganie przymusowego wykupu akcji jako „prywatnoprawnego wywłaszczenia". Tak D. Dąbrowska, Przymusowy wykup akcji a istota prawu własności, „Prawo Spółek” 2004, nr 11, s. 19 i n.

${ }^{67}$ R. Pabis, Komentarz do art. 418, w: Kodeks spółek handlowych, t. 3B: Spółka akcyjna, pod red. A. Opalskiego, Warszawa 2016, s. 478 i n.

${ }^{68}$ A. Kappes, Szantaż korporacyjny jako nadużycie prawa podmiotowego, „Przegląd Prawa Handlowego" 2013, nr 10, s. 46 i n.

${ }^{69}$ A. Szumański, Pokrzywdzenie akcjonariusza..., s. 6.

${ }^{70}$ A. Szumański, Przymusowy wykup akcji..., s. 2-3. 


\section{majątkowym powoduje częste kolizje między dobrami chronionymi} na podstawie różnych tytułów prawnych, gdy oba kolidujące prawa korzystają z konstytucyjnej gwarancji własności ${ }^{71}$.

W przypadku instytucji przymusowego wykupu mamy do czynienia z tradycyjnym zderzeniem interesów dwóch podmiotów, w związku z czym na płaszczyźnie prawnokonstytucyjnej konieczne jest dokonanie ważenia dóbr. Tego rodzaju konflikt nie jest czymś nadzwyczajnym $\mathrm{w}$ prawie konstytucyjnym ${ }^{72}$, podobnie jak w całej argumentacji prawniczej, gdzie wykładnię postrzegać można przez pryzmat ważenia prawniczych argumentów ${ }^{73}$. W przeciwieństwie jednak do typowych jednogatunkowych - w prawie konstytucyjnym konfliktów wartości w tym wypadku wartości pozostające $\mathrm{z}$ sobą w sprzeczności nie są odmienne rodzajowo. Obydwa interesy wynikają bowiem z konstytucyjnego prawa własności ${ }^{74}$. Realizacja prawa własności akcjonariuszy większościowych - których prawo ex nature jest silniejsze z racji większej ilości reprezentowanego kapitału - oddziałuje na prawa majątkowe akcjonariuszy wykupywanych. W tym wypadku dopatrywać się można przełamania prawa akcjonariusza mniejszościowego poprzez przyznanie prymatu prawu o wiele silniejszemu. Przy takim ujęciu można argumentować, że nie następuje unicestwienie prawa akcjonariusza wykupywanego, jedynie ustępuje ono miejsca prawu silniejszemu, które w przeciwnym razie nie mogłoby być zrealizowane, ergo z jego silniejszego charakteru nic by nie wynikało. Takie rozumowanie wydaje się uzasadnione w świetle teorii ważenia wartości i praw Roberta Alexy'ego ${ }^{75}$. Teoria ta, nawiązując do Dworkinowskiego podziału norm na reguły i zasady ${ }^{76}$, nakazuje ważenie zasad (wartości), nie jest bowiem możliwe zadośćuczynienie obydwu. Przy czym podkreślenia wymaga,

${ }^{71}$ E. Łętowska, Własność i jej ochrona jako wzorzec kontroli konstytucyjności. Wybrane problemy, "Kwartalnik Prawa Prywatnego” 2009, nr 4, s. 914.

72 Były sędzia TK Marek Safjan zwraca uwagę, że ważenie racji zajmuje ważny element kultury demokratycznej i całej debaty publicznej (nie ogranicza się więc jedynie do dyskursu prawnego). Zob. M. Safjan, Wyzwania dla państwa prawa, Warszawa 2007, s. $79-80$.

${ }^{73}$ T. Spyra, Granice wykładni prawa. Znaczenie językowe tekstu prawnego jako granica wykładni, Zakamycze 2006, s. 246 i n.

${ }^{74}$ Podobnie można by postrzegać instytucję bankowego tytułu egzekucyjnego, która ułatwiając ochronę praw majątkowych wierzyciela, wywierała wpływ na prawa majątkowe dłużnika. Zob. K. Nowakowska, P. Ochmann, op. cit., s. 107.

${ }^{75}$ R. Alexy, Teoria praw podstawowych, Warszawa 2010, s. 78.

${ }^{76}$ M. Pełka, Teoria ważenia dóbr w ujęciu Roberta Alexy'ego w kontekście wyroku TK w sprawie uboju rytualnego, „Przegląd Filozoficzny - Nowa Seria” 2015, nr 2(94), s. 262. 
że zasady w ujęciu Alexy'ego powiązane są z wartościami: „stopniowalności realizacji zasady odpowiada stopniowalność urzeczywistniania wartości"77. Aplikując teorię na poziom konkretny, można by powiedzieć, że wartość w postaci praw, jakimi są akcje akcjonariusza wykupywanego, ustępuje wartości w postaci praw wynikających z akcji akcjonariusza większościowego albo, innymi słowy, że zasada rządów większości nad mniejszością wynikająca także z akcji i całego uregulowania spółki akcyjnej zostanie urzeczywistniona bardziej, jeżeli zasada ochrony akcjonariusza mniejszościowego - która przecież pomimo występowania instytucji przymusowego wykupu wciąż obowiązuje - w tym wypadku będzie realizowana w mniejszym stopniu. Jak bowiem wskazuje P. Tuleja, przeważenie zasady nie oznacza jej usunięcia z systemu prawa, ale jedynie w indywidualnych przypadkach - tu, gdy spełnione są przesłanki z art. 418 k.s.h. - jest ona odsunięta na bok ${ }^{78}$.

\section{Specyfika prawa handlowego na płaszczyźnie prawnokonstytucyjnej}

Specyfika prawa handlowego przejawiałaby się m.in. na płaszczyźnie prawnokonstytucyjnej tym, że częściej niż w innych dziedzinach prawa pozostające ze sobą w kolizji dobra miałyby ten sam charakter ${ }^{79}$. Ważenie odbywałoby się zatem w ramach tego samego dobra, które jednak przysługuje przynajmniej dwóm podmiotom o niezgodnych interesach. W owym ważeniu dopatrywać by się można pewnej ambiwalencji. $\mathrm{Z}$ jednej strony bowiem $\mathrm{z}$ perspektywy dokonywanego procesu intelektualnego balansowanie nie różniłoby się od typowego ważenia dóbr (pomimo jego jednorodności w postaci jednego dobra - prawa własności), a zatem w ramach tego dobra konieczne byłoby wyodrębnienie i zestawienie przeciwstawnych interesów. $Z$ drugiej jednak strony owe interesy czerpałyby swe źródło w tym samym prawie konstytucyjnym,

${ }^{77}$ M. Kordela, Możliwość konstruowania ogólnej teorii zasad prawa. Uwagi do koncepcji Roberta Alexy'ego, „Ruch Prawniczy, Ekonomiczny i Socjologiczny” 2007, z. 2, s. 25.

${ }^{78}$ P. Tuleja, Normatywna treść praw jednostki w ustawach konstytucyjnych RP, Warszawa 1997, s. 71.

${ }^{79}$ Innym przykładem w prawie gospodarczym, gdy w kolizji wobec siebie pozostaje prawo własności dwóch podmiotów, jest bankowy tytuł egzekucyjny, który ułatwiając dochodzenie roszczeń wierzycielowi (bankowi), mógł wpływać ujemnie na sferę praw majątkowych dłużnika. Obszerne omówienie relacji bankowego tytułu egzekucyjnego względem prawa własności zob. K. Nowakowska, P. Ochmann, op. cit., s. 112. 
w dodatku miałyby one charakter złożony i wzajemnie się przeplatający: zarówno bowiem interes akcjonariusza większościowego, jak i interes akcjonariusza mniejszościowego może pokrywać się niekiedy z interesem spółki, który - ogólnie rzecz biorąc - należy traktować w sposób odrębny od interesów wspólników spółki kapitałowej. Ponadto pomimo ważenia dóbr w ramach tej samej wartości konstytucyjnej (ochrony własności) w sposób pośredni można wywieść - jak przeważnie w każdej sprawie kontroli konstytucyjnej - dobra dodatkowe (jak np. zasada równości, prawo do sądu), co powoduje z kolei upodobnienie i powrót do ogólnego ważenia dóbr (interesów). Można by odnieść wrażenie swoistego błędnego koła. Na tym właśnie polega ambiwalencja ważenia dóbr przy ocenie regulacji z k.s.h. - na pierwszej płaszczyźnie wykazują one charakter odróżniający, na drugiej natomiast zauważyć można cechy wspólne z każdą inną sprawą kontroli konstytucyjności i dokonywanego przy jej okazji ważenia.

Zarazem specyfika prawa handlowego - której podstaw można upatrywać w konstytucyjnie chronionej wolności jednostki i przysługujących jej praw - wyraża się w dobrowolności podlegania jej regulacjom. To podmioty prawa cywilnego, podejmując określoną aktywność, decyduja, że będą podlegały tej regulacji. Oczywiście, taka swoboda nie jest czymś charakterystycznym wyłącznie dla prawa handlowego wszak oznacza ona jedynie zasadę autonomii woli podmiotów prawa prywatnego. Zarazem jednak osoby podlegające regulacjom prawa handlowego mają charakter kwalifikowany, w związku z czym można argumentować, że stosowanie wobec nich (pod warunkiem, iż dotyczy to wyłącznie ich samych) innych konstytucyjnych standardów jest legitymizowane. Kwalifikowany charakter, o którym w tym miejscu mowa, nie jest równoznaczny z prostym uznaniem za przynależność do obrotu profesjonalnego. O ile bowiem, w przypadku spółek handlowych, same spółki tworzone są do prowadzenia działalności gospodarczej, o tyle ich wspólnicy wcale przedsiębiorcami być nie muszą. W przypadku uczestników rynków kapitałowych duża ich część to przecież tylko drobni inwestorzy, którzy posiadając np. akcje, dokonują określonej dywersyfikacji swego portfolio, poszukując optymalnej alokacji posiadanych kapitałów. Jednakże decydując się na udział w spółce kapitałowej, powinni liczyć się z zasadami rządzącymi spółkami handlowymi. Stąd w odniesieniu do nich wykładnia wzorców konstytucyjnych może nawiązywać do tej złożoności, pozwalając na autonomiczne ujęcie. Decydując się bowiem w sposób dobrowolny na przystąpienie do spółki, 
akceptuje się określone ograniczenia wynikające z jej specyfiki, co postrzegać można jako pewien element ryzyka, w zamian otrzymując możliwość partycypacji w zyskach pochodzących z kształtu posiadanych praw podmiotowych.

Przy instytucji przymusowego wykupu pozbawienie praw majątkowych następuje wbrew woli akcjonariuszy wykupywanych. Abstrahując od relacji wertykalnej - względem samych wzorców konstytucyjnych warto spojrzeć na aspekt horyzontalny, a mianowicie odnieść się do ogólnych wzorców prawa prywatnego, którego prawo handlowe, stosownie do zasady jednolitości prawa cywilnego, stanowi immanentną część. Jednakże wnioski wynikające ze spojrzenia horyzontalnego również pokazują pewnego rodzaju specyfikę, którą postrzegać można jako swoiste ograniczenie względem zasad ogólnych. Już na etapie tworzenia spółki limitowana zostaje autonomia woli i zasada swobody kontraktowania ${ }^{80}$ poprzez możliwość wyboru tylko takiej formy spółki, jaką przewiduje k.s.h. (zasada numerus clausus spółek handlowych ${ }^{81}$ ). Dalej, w przypadku modelowej spółki kapitałowej, jaką jest spółka akcyjna, swoboda wykonywania przysługujących praw majątkowych doznaje znacznych ograniczeń. Z perspektywy akcjonariusza mniejszościowego zaliczyć można do nich także możliwość jego potencjalnego wyciśnięcia. Spojrzenie przez pryzmat horyzontalny na prawo spółek kapitałowych (w relacji do ogólnych zasad prawa cywilnego) uzasadnia wniosek, że status podmiotu nim dotkniętego narażony może być na ograniczenia przysługujących mu praw i wolności. Taka jest jednak specyfika prawa gospodarczego oraz handlowego i - ponieważ decydując się na wejście w jego obszar, należy się z nią liczyć - trudno upatrywać w tym naruszenia praw. Rozumowanie to można zasadnie ekstrapolować na aspekt wertykalny, a więc w odniesieniu regulacji k.s.h. do wzorców konstytucyjnych, np. prawa własności.

Przy ocenie regulacji k.s.h. na tle konstytucyjnego prawa własności uwzględniony powinien być zatem szczególny charakter prawa spółek. Prawo własności (sensu largo) na obszarze spółek kapitałowych może być zdeterminowane w przypadku każdej jednostki siłą tegoż prawa na nią przypadającą w odniesieniu do siły praw innych jednostek.

${ }^{80} \mathrm{~W}$ doktrynie przymusowy wykup nazywany bywa "wyłomem od zasady swobody umów". Tak P. Wierzbicki, Uchwała o przymusowym wykupie akcji - "wyciśnięcie” drobnych akcjonariuszy, "Prawo Spółek” 2003, nr 5, s. 2.

${ }^{81}$ W. Pyzioł, Spółka cywilna, w: W. Pyzioł, A. Szumański, I. Weiss, Prawo spółek, Bydgoszcz-Kraków 2006, s. 29. 
Zarazem z akcji stanowiącej substrat tego prawa w spółce kapitałowej wynikać mogą inne prawa. Jednym z nich jest prawo do zaskarżenia uchwały, które wszak pod względem konstytucyjnym bliższe mogłoby się wydawać prawu do sądu z art. 45 Konstytucji RP. Na płaszczyźnie k.s.h. prawo do zaskarżenia uchwały WZA stanowi wszakże jedno z tzw. praw korporacyjnych ${ }^{82}$, które składają się na akcję rozumianą jako wiązka uprawnień, czy też prawo podmiotowe, z którego wynikają poszczególne uprawnienia. Źródłem prawa do zaskarżenia uchwały jest więc prawo majątkowe chronione konstytucyjnym prawem własności.

\section{Zaskarżanie uchwał zgromadzeń w świetle standardów konstytucyjnych}

Kodeks spółek handlowych w art. 422 § 2 dla spółki akcyjnej oraz $\mathrm{w}$ art. 250 dla spółki z ograniczoną odpowiedzialnością wymienia podmioty uprawnione do wniesienia powództwa o uchylenie uchwały zgromadzenia wspólników/WZA oraz powództwa o stwierdzenie jej nieważności (art. $252 \S 1$ k.s.h. oraz art. $425 \S 1$ k.s.h. odsyłają do podmiotów wymienionych uprzednio przy powództwie o uchylenie uchwały). Wymienione tam podmioty tworzą katalog zamknięty. Enumeratywny charakter owego wyliczenia przyjmowany jest jednomyślnie w doktrynie prawa ${ }^{83}$. Jak zauważa K. Kruczalak, w umowie spółki lub późniejszej uchwale wspólników nie można prawa wniesienia powództwa przyznać innym podmiotom lub modyfikować treści owego kata$\log \mathrm{u}^{84}$. Oznacza to, że tylko podmioty wymienione $w$ tych przepisach mogą skorzystać z powództwa o stwierdzenie nieważności (albo o uchylenie) uchwały. Wskazuje się ponadto, iż „założeniem ustawodawcy było stworzenie ograniczonego czasowo (poprzez terminy zawite), przedmiotowo (przez sprecyzowanie przesłanek uchylenia i stwierdzenia nieważności) oraz podmiotowo (przez enumeratywne określenie osób uprawnionych do zaskarżenia) systemu zaskarżenia, tak aby ograniczyć

${ }^{82}$ A. Szumański, Spółka akcyjna, w: W. Pyzioł, A. Szumański, I. Weiss, Prawo spółek, Warszawa 2014, s. 871 i n.

${ }^{83}$ A. Jarocha, Legitymacja do żądania stwierdzenia przez sąd nieważności uchwał zgromadzenia wspólników, „Prawo Spółek” 2004, nr 12; R. Czerniawski, Kodeks spółek handlowych. Przepisy o spółce akcyjnej. Komentarz, Warszawa 2004.

${ }^{84}$ K. Kruczalak, Art. 250, w: J. Frąckowiak, A. Kidyba, K. Kruczalak, W. Opalski, W. Popiołek, W. Pyzioł, Kodeks spółek handlowych. Komentarz, Warszawa 2001, s. 178. 
i uczynić przewidywalnym proces kwestionowania uchwał zgromadzeń spółek kapitałowych"85.

Ogólnie rzecz biorąc, podmioty z art. 250 k.s.h. oraz z art. $422 \S 2$ k.s.h. tworzą dwie grupy: funkcjonariuszy spółki (działających albo pojedynczo, albo in corpore w charakterze organu osoby prawnej) oraz jej właścicieli (wspólników, akcjonariuszy). Przyjmuje się również, że w wyniku praktyki orzeczniczej Sądu Najwyższego (SN) wykształciła się trzecia grupa podmiotów legitymowanych, dla której podstawę stanowią przepisy poza Kodeksem spółek handlowych ${ }^{86}$.

Mimo że prima facie katalog osób legitymowanych wydawać by się mógł w pełni klarowny i wykluczający jakiekolwiek nieścisłości, $\mathrm{w}$ praktyce pojawiły się problemy interpretacyjne $\mathrm{z}$ określeniem zakresu poszczególnych jej kategorii. Jak stwierdza K. Strzelczyk ${ }^{87}$, tylko pozornie treść art. 250 k.s.h. jest jasna i nie powinna budzić wątpliwości. Tymczasem katalog podmiotów uprawnionych do zaskarżenia uchwał wywoływał i wywołuje liczne kontrowersje, w szczególności w odniesieniu do zagadnienia legitymacji czynnej odwołanych członków organów spółek kapitałowych oraz byłych wspólników ${ }^{88}$. Jak zauważa K. Bilewska, restryktywny sposób postrzegania katalogu osób uprawnionych do zaskarżania sprzecznych z prawem uchwał zgromadzenia spółki jest $\mathrm{w}$ doktrynie negowany przede wszystkim ze względu na sytuację byłego członka organu spółki, który został odwołany na podstawie uchwały sprzecznej z prawem ${ }^{89}$. Sprawę odwołanych piastunów rozwiązała jednak definitywnie uchwała SN o sygn. III CZP 94/06 ${ }^{90}$, wykluczając taką możliwość.

Warte uwagi jest natomiast spojrzenie na sytuację byłego wspólnika spółki kapitałowej. Czy, skoro byłemu członkowi zarządu (rady nadzorczej) odmawia się legitymacji do zaskarżenia uchwały go odwołującej, to

${ }^{85} \mathrm{~K}$. Bilewska, Tendencje w kształtowaniu się katalogu podmiotów uprawnionych do zaskarżania uchwał zgromadzeń spótek kapitałowych, "Przegląd Prawa Handlowego" 2014, nr 9, s. 51.

${ }^{86}$ Ibidem, s. 50-54.

${ }^{87}$ K. Strzelczyk, Komentarz do art. 250 KSH, w: Kodeks spótek handlowych. Komentarz, t. 2, pod red. R. Potrzeszcza, T. Siemiątkowskiego, J.P. Naworskiego, J. Rodziewicza, K. Strzelczyk, Warszawa 2011.

${ }^{88}$ Ibidem.

${ }^{89} \mathrm{~K}$. Bilewska, Zaskarżanie uchwał zgromadzenia wspólników przez odwołanych członków organów spótki, "Monitor Prawniczy” 2007, nr 19, s. 1099.

${ }^{90}$ Uchwała SN z 1 III 2007 r., sygn. III CZP 94/06, OSNC 2007, nr 7-8, poz. 95, dostępna także w Biuletynie SN 2007, nr 3. 
tym samym takiej legitymacji pozbawiony winien być także były wspólnik w stosunku do uchwały pozbawiającej go członkostwa w spółce? Sąd Najwyższy w wyroku o sygn. IV CSK 41/05 przyjął, że były akcjonariusz zachowuje legitymację do zaskarżenia uchwały walnego zgromadzenia, która dotyczy jego praw korporacyjnych lub majątkowych, traci natomiast legitymację do zaskarżania uchwał, które nie dotykają jego praw $^{91}$. Dopuszczalność zaskarżenia uchwały zgromadzenia przez byłego wspólnika, która dotyczy jego praw korporacyjnych lub majątkowych, została potwierdzona w wyroku SN o sygn. I CSK 94/0992, w którym Sąd powołał się na wcześniejsze orzeczenie. Przyjęcie przez Sąd Najwyższy w 2010 r. również takiego rozstrzygnięcia, uznającego legitymację do zaskarżenia uchwały zgromadzenia w przedmiocie przymusowego umorzenia udziałów wspólnika, pozwala mówić już o utrwalonej linii orzeczniczej w tej materii ${ }^{93}$. O ile zatem SN wykluczył legitymację odwołanego członka zarządu albo rady nadzorczej, to dopuszcza on możliwość zaskarżenia niektórych uchwał przez byłego wspólnika. W doktrynie podniesiono, że takie zróżnicowanie statusów tych osób nie znajduje uzasadnienia, gdyż ich sytuacja nie jest jakoś szczególnie odmienna, w efekcie czego zachodzi tutaj niekonsekwencja Sądu ${ }^{94}$.

Jednakże można by podać w wątpliwość, czy rzeczywiście status byłego wspólnika i odwołanego członka organu menedżerskiego nie jest odmienny. Były wspólnik uzyskał taki status wskutek pozbawienia go prawa własności, jest zatem czymś naturalnym, że w celu ochrony tego prawa powinien on mieć możliwość zakwestionowania prawidłowości owego pozbawienia. Natomiast były członek zarządu czy rady nadzorczej, który został odwołany uchwałą WZA, zmienia swój status wskutek realizacji prawa własności przysługującego innym podmiotom. W tym wypadku zatem nie ma konfliktu z jego prawem własności. Ewentualnie jego pozycję można by rozważać przez pryzmat naruszenia prawa do sądu (w tym wypadku można by dopatrywać się zderzenia wartości w postaci prawa do sądu odwołanego członka zarządu z możliwością swobodnego rozporządzenia swymi prawami

${ }^{91}$ Wyrok SN z 7 II 2006 r., sygn. IV CSK 41/05, OSP 2006, nr 9, poz. 108, dostępny także w Systemie Informacji Prawnej LEX nr 191535.

${ }^{92}$ Wyrok SN z 15 X 2009 r., sygn. I CSK 94/09, Biuletyn SN 2009, nr 12, poz. 11.

${ }^{93}$ Zob. wyrok SN z 9 IX 2010 r., sygn. I CSK 530/09, OSNC 2011, nr 3, poz. 36, dostępny także w Biuletynie SN 2010, nr 12, poz. 14.

${ }_{94}$ M. Bieniak, Glosa do wyroku SN z dn. 9 września 2010 r., I CSK 530/09. Legitymacja byłego wspólnika do zaskarżania uchwały zgromadzenia wspólników spótki z ograniczoną odpowiedzialnościa, "Glosa” 2012, nr 2, s. 39-42. 
podmiotowymi). Jednakże TK uznał brak możliwości takiego zaskarżenia za zgodny z Konstytucją RP ${ }^{95}$. Możliwość zaskarżenia uchwały pozbawiającej wspólnika członkostwa w spółce traktować można jako wyraz prokonstytucyjnej wykładni mającej na celu urzeczywistnienie konstytucyjnej ochrony przysługującej mu własności.

Zarazem warto by się zastanowić, czy w świetle konstytucyjnego prawa własności możliwość zaskarżenia uchwały - w sensie ogólnym, a więc nie tylko pozbawiającej wspólnika członkostwa - jest wymogiem koniecznym dla konstytucyjności funkcjonowania spółki kapitałowej. Innymi słowy, czy gdyby akcjonariusz nie posiadał możliwości zaskarżenia uchwały WZA, to doszłoby do naruszenia jego prawa własności. Albo jeżeli zaskarżenie takie miałoby charakter prawa kolektywnego, co oznaczałoby możliwość korzystania z niego tylko przy reprezentowaniu określonego ułamka kapitału zakładowego. Propozycje takie nie stanowią bynajmniej zupełnie abstrakcyjnych dywagacji, zgłaszane były już nawet w doktrynie. A. Radwan i Ł. Gorywoda postulują ograniczenie możliwości zaskarżania uchwał tylko do osób posiadających odpowiednią wielkość udziałów w spółce, wskazując zarazem, że w przypadku stworzenia odpowiedniego mechanizmu kompensacyjnego rozwiązanie takie nie naruszałoby ani konstytucyjnych standardów prawa do sądu i ochrony własności, ani nie byłoby niemożliwe na gruncie zasady równouprawnienia akcjonariuszy ${ }^{96}$. Biorąc pod uwagę poczynione rozważania, należy ocenić taki pomysł jako dopuszczalny w świetle konstytucyjnego prawa własności. Ograniczenie zakresu zaskarżania wzmacniałoby niewątpliwie stabilizację stosunków spółki, co pośrednio oznaczać by mogło ochronę własności akcjonariuszy większościowych. Przykład ten od strony konstytucyjnoprawnej zdaje się być bliźniaczo podobny do rozważanego przymusowego wykupu - w celu ochrony prawa własności pewnych wspólników konieczne jest ograniczenie prawa własności innych. Pokazuje on przy tym, jak często dochodzi do konieczności ważenia interesów mających swą podstawę w ramach tego samego prawa konstytucyjnego ${ }^{97}$. Zarazem uzasadnia nakreślony

${ }^{95}$ Wyrok TK z 2 VI 2009 r., sygn. SK 31/08, OTK ZU 2009, nr 6, poz. 83.

${ }_{96}$ A. Radwan, Ł. Gorywoda, Zaskarżanie uchwał walnego zgromadzenia akcjonariuszy. Reformy w Europie i wnioski dla polskiego ustawodawcy, "Kwartalnik Prawa Publicznego” 2009 , z. 2, s. 437-493.

${ }^{97}$ Powyższe stwierdzenie nie oznacza, że owo ważenie ogranicza się tylko do jednej wartości - poza prawem własności przysługującym zarówno wspólnikom większościowym, jak i mniejszościowym, konieczne będzie balansowanie także innych dóbr, jak konstytucyjne prawo do sądu. 
powyżej sposób postrzegania specyfiki prawa spółek handlowych w obrębie sfery konstytucyjnej. Prawa i wolności określone w Konstytucji RP zdają się być na tyle elastyczne, że zapewniają ochronę także przy uwzględnieniu pewnej autonomiczności prawa handlowego w ramach prawa konstytucyjnego.

\section{Podsumowanie}

Reasumując powyższe rozważania, zasadne zdaje się twierdzenie, że ocena konstytucyjności instytucji Kodeksu spółek handlowych wymaga uwzględnienia ich charakteru. Ze względu na specyfikę stosunków prawa handlowego do obrony zdaje się być teza o pewnej autonomii prawa handlowego wobec ogólnych zasad wynikających z prawa konstytucyjnego. Autonomia ta nie modyfikuje, oczywiście, ustawy zasadniczej - gdyż ta jako najwyższe źródło prawa nie mogłaby takim modyfikacjom podlegać - tylko wpływa na sposób jej wykładni i dokonywanych zabiegów interpretacyjnych. Prowadzi to w konsekwencji do sytuacji, że wiele regulacji, które prima facie mogłyby budzić wątpliwości co do ich konstytucyjności, po bliższym ich poznaniu będzie pod względem konstytucyjnym akceptowalnych ze względu na naturę spółki handlowej.

\section{SELECTED REGULATIONS OF THE CODE OF COMMERCIAL PARTNERSHIPS AND COMPANIES IN THE LIGHT OF THE CONSTITUTIONAL MODEL OF THE RIGHT OF OWNERSHIP PROTECTION}

\section{S u m mary}

The article confronts specific solutions adopted in the Code of Commercial Companies and Partnerships with the patterns of the constitutional control of law resulting from the Constitution of the Republic of Poland in the form of the right of ownership. Its aim is to answer the question whether the constitutionality of commercial law institutions should be assessed autonomously, taking into account the specificity of commercial companies law. The author puts forward a thesis that just as there is a principle of autonomy of commercial law within the principle of unity of civil law, within the framework of constitutional law, the regulations of law and commerce also have autonomy which influences the process of assessing the conformity of particular subjects of control with the models defined in the Constitution of the Republic of Poland. As one of the specific elements of commercial law in relation 
to the Constitution, the necessity of weighing the opposing interests of the same good, i.e. the right to ownership is pointed out. The paper discusses in detail the institution of forced buyout (squeeze-out) in the context of the judgment of the Constitutional Tribunal (Case No. P 25/02). The issue of legitimacy to appeal against the resolution of the General Shareholders Meeting of a company from the point of view of the right of ownership is also discussed. In the author's opinion, the right to appeal against the resolution, which prima facie at the constitutional law level could be associated with the constitutional right to a court, takes the form of a corporate right of a shareholder resulting from a constitutional right of ownership, of which a share is one of the forms. Therefore, it has a derivative character. The considerations contained in the text lead to the recognition of the admissibility of an autonomous interpretation of company law regulations when assessing their compliance with the Constitution. When assessing constitutionality, the legal character and specificity of the subject of control should be taken into account.

Keywords: forced buyout - squeeze-out - weighing of goods - autonomy of commercial law 